\title{
A Study on Psychological Well-Being among Employees of I.T Companies
}

\author{
M. Rajeswari ${ }^{1} \&$ R. Magesh ${ }^{1}$ \\ ${ }^{1}$ Department of Management Studies, Hindustan University, Padur, Chennai, India \\ Correspondence: M. Rajeswari. E-mail: mmraji75@gmail.com \\ Received: April 22, 2017 \\ Accepted: May 19, 2017 Online Published: July 25, 2017 \\ doi:10.5539/ass.v13n8p59 \\ URL: https://doi.org/10.5539/ass.v13n8p59
}

\begin{abstract}
Liberalization of the Indian organizational environment through modification in the industrial, trade and financial policies by the government has brought in change and competition of a magnitude that was previously unknown to Indian business. In the present scenario, where multinationals and other global players are competing in the domestic market with the monopoly players, the management of organizations is expected to be more productive and efficient for survival in India. More than a decade ago, the western countries faced similar conditions. A flow of changing organizational structures and changing expectations has forced various departments of the organization to alter their perspectives on their role and function overnight. In this context, it would be important to identify the factors in the organizational environment that have the most positive as well as negative impact on their performance in the organization in order to facilitate the positive and impede negative factors at job setting. Hence, the present research was undertaken to find out, how occupational stress and human resource practices can contribute to psychological well-being among employees of I.T companies.

The main factors affecting the job satisfaction of the I.T. employees are based on Age, Gender, Educational qualification, Marital status, Experience, Salary, Nature of employment. The data collected will be analyzed with the usage of the statistical tools like one way ANOVA, factor analysis and independent t- test. The major findings are reported at the completion of the project work and on the basis of the study, suitable suggestions will be given to the company.
\end{abstract}

Keywords: well being, productivity, job satisfaction, counselling

\section{Introduction}

Job satisfaction is a very important attribute and it is believed that- "the happier the people are within their job, the more satisfaction they are said to have". It is indispensable for the company to know about the factors which the employees value the most and understanding the employees is a dynamic and evolving process.

The people are considered to be the most valuable asset of the organization. Companies who acknowledge the above fact continually invest in hiring skilled people and train them according to their requirements. Only satisfied employees will show enthusiasm in the job.

The people with high levels of satisfaction and motivation are an asset to any organization and they will display a positive attitude and cheerfulness, at all times. They adapt to the changes quickly and go an extra mile for the welfare of the organization. They are the "go-getters" and these pillars of strength hold the team/organization together in times of adversity or challenge. Organization with engaged, satisfied, motivated workforce consistently outperforms larger companies with disillusioned and unenthusiastic staff.

Behavioural researches and HR professionals agree that job satisfaction is important for an organization.

\subsection{Objectives}

\subsubsection{Primary Objective}

To study the psychological well-being and the overall job satisfaction level of the employees of I.T Companies in Chennai.

\subsubsection{Secondary Objectives}

- To study the relation between job satisfaction and hygiene level provided by the I.T Companies in Chennai. 
- $\quad$ To study the relation between perception and psychological well-being of the employees of I.T Companies in Chennai.

- To study the impact of personal variables such as Age, Gender, Educational qualification, Marital status, Experience, Salary, Nature of employment.

- To evolve effective suggestions in order to improve the level of the job satisfaction among the employees of IT companies of Chennai.

\section{Literature Review}

Wilson et al (2004) in their study observed negative correlation of job satisfaction with stress and depression. However, in the same study, job satisfaction was found to be a positively related with the general health of the employees, In another study Wright and Bonnet(2007) obtained a positive correlation between job satisfaction and psychological well-being some other previous studies have also shown similar results.

The deprivation/domination paradigm postulates that the higher the deprivation of a need, the higher its need strength. An early review concluded that the deprivation/domination paradigm was only partially supported for self-actualization, and not supported for safety, belongingness and esteem needs (Wahba \& Bridwell, 1976). On the basis of this review, many researchers have assumed that the proposition is not supported (Wicker et al., 1993). This assumption may be inaccurate however, as many of the studies included in the review have methodological limitations. These limitations concern: a) the operationalisation of need strength; and b) establishing causality.

Hall and Nougaim (1968) conducted a longitudinal study on managers, interviewing them annually for five years. The participants rated the importance of satisfaction with a number of needs including safety, affiliation, achievement and esteem, and self-actualization.

\section{Methodology}

Employees from the I.T companies in Chennai are taken as the sample of the study. Random sampling technique is used and 150 employees were selected. The data was analysed using percentage analysis, independent $t$ test and factor analysis.

\section{Data Analysis}

\subsection{Factor Analysis}

To measure the sampling adequacy and the usefulness of the data KMO and Bartlett's, test of Sphericity is used.

Table 1. KMO and Bartlett's Test

\begin{tabular}{lcc}
\hline Kaiser-Meyer-Olkin Measure of Sampling Adequacy. & .842 \\
\hline & Approx. Chi-Square & $2.141 \mathrm{E} 3$ \\
Bartlett's Test of Sphericity & df & 120 \\
& Sig. & .000 \\
\hline
\end{tabular}

The result shows that the correlation between the variables under each factor is significantly strong, that is justified with the Chi-square value in the table. The adequacy of the sample is ascertained using the KMO measure of sample adequacy which is 0.842 which is more than the acceptable 0.6 .

Table 2. Total Variance Explained

\begin{tabular}{cccccccccc}
\hline \multirow{2}{*}{ Component } & \multicolumn{3}{c}{ Initial Eigenvalues } & \multicolumn{3}{c}{$\begin{array}{c}\text { Extraction Sums of Squared } \\
\text { Loadings }\end{array}$} & \multicolumn{2}{c}{ Rotation Sums of Squared Loadings } \\
\cline { 2 - 9 } & Total & $\begin{array}{c}\text { \% of } \\
\text { Variance }\end{array}$ & Cumulative \% & Total & $\begin{array}{c}\text { \% of } \\
\text { Variance }\end{array}$ & Cumulative \% & Total & $\begin{array}{c}\text { \% of } \\
\text { Variance }\end{array}$ & Cumulative \% \\
\hline 1 & 8.723 & 54.521 & 54.521 & 8.723 & 54.521 & 54.521 & 5.169 & 32.308 & 32.308 \\
2 & 1.684 & 10.527 & 65.049 & 1.684 & 10.527 & 65.049 & 2.720 & 16.998 & 49.306 \\
3 & 1.045 & 6.532 & 71.581 & 1.045 & 6.532 & 71.581 & 2.388 & 14.927 & 64.233 \\
4 & .884 & 5.523 & 77.104 & .884 & 5.523 & 77.104 & 2.059 & 12.870 & 77.104 \\
5 & .763 & 4.767 & 81.871 & & & & & & \\
\hline
\end{tabular}




\begin{tabular}{llll}
\hline 6 & .563 & 3.521 & 85.391 \\
7 & .523 & 3.269 & 88.661 \\
8 & .473 & 2.956 & 91.617 \\
9 & .340 & 2.123 & 93.740 \\
10 & .218 & 1.362 & 95.102 \\
11 & .214 & 1.336 & 96.438 \\
12 & .196 & 1.225 & 97.664 \\
13 & .120 & .750 & 98.414 \\
14 & .106 & .662 & 99.076 \\
15 & .081 & .508 & 99.583 \\
16 & .067 & .417 & 100.000
\end{tabular}

Table 3. Rotated Component Matrix

\begin{tabular}{|c|c|c|c|c|}
\hline & \multicolumn{4}{|c|}{ Component } \\
\hline & factor 1 & factor 2 & factor 3 & factor 4 \\
\hline 3.) My chances for advancement in the organization & .850 & & & \\
\hline 6.) Overall I feel my career goals can be met in my organization & .838 & & & \\
\hline 2.) When I do an excellent job my accomplishments are recognized. & .774 & & & \\
\hline 14.) In my organization, people are rewarded according to their job performance. & .770 & & & \\
\hline 11.) I understand how my performance is evaluated. & .715 & & & \\
\hline 4.) I am paid fairly for the contributions I make to the organization`s success. & 675 & & & \\
\hline 10.) I receive ongoing feedback that helps me improve my performance. & 665 & & .525 & \\
\hline 1.) Goals set by the Organization for me & & .767 & & .426 \\
\hline 5.) My manager and I have identified ways I can develop in my career. & & 678 & & \\
\hline 7.) My relationship with my co-workers & & 666 & & \\
\hline 8.) I feel free to take informed risks in getting my work done. & & .614 & & \\
\hline $\begin{array}{l}\text { 9.) I have the technology tools and services I need to support me in how and where I } \\
\text { work. }\end{array}$ & & 607 & .464 & \\
\hline 12.) My organization does not sacrifice quality simply to achieve a goal or metric. & & & .888 & \\
\hline 13.) Processes and procedures allow me to effectively meet my customers` needs. & & & .784 & \\
\hline 16.) Medical insurance policies and educational support provided & & & & .854 \\
\hline 15.) Pension, HRA and Commutation allowances provided & & & & .794 \\
\hline
\end{tabular}

From the above table the following factors were identified.

4.1.1 Factor Variable 1

Organizational Factors

- Chances for advancement in the organization have higher influence.

- Ongoing feedback that helps to improve the performance has lower influence.

\subsubsection{Factor Variable 2}

\section{Relationship with Co-Workers}

- Relationship with my co-workers has higher influence.

- Technology, tools and services at workplace have lower influence.

4.1.3 Factor Variable 3

Support, Quality, Procedures and Process 
- Organization does not sacrifice quality simply to achieve a goal or metric have higher influence.

- Technology, tools and services at workplace have lower influence.

\subsubsection{Factor Variable 4}

- Medical insurance policies and educational support provided metric have higher influence.

- Goals set by the Organization have lower influence.

\subsection{Factor Analysis on Psychological Well Being}

The result in the table 4 shows that the correlation between the variables under each factor is significantly strong, that is justified with the Chi-square value in the table. The adequacy of the sample is ascertained using the KMO measure of sample adequacy which is 0.788 which is more than the acceptable 0.6 .

In the exploratory factor analysis, principle component analysis is applied for the extraction of the factors. Varimax rotation method is used for rotating the matrix. Factors with Eigen value of more than one are only taken for analysis and statements with loading factor less than .40 are suppressed. Based on their correlation within the groups, all the sixteen statements on psychological well being are grouped into two factors namely, like the job and it's a stressful job.

Table 4. KMO and Bartlett's Test

\begin{tabular}{|c|c|c|}
\hline \multicolumn{2}{|c|}{ Kaiser-Meyer-Olkin Measure of Sampling Adequacy. } & .788 \\
\hline \multirow{3}{*}{ Bartlett's Test of Sphericity } & Approx. Chi-Square & $1.218 \mathrm{E} 3$ \\
\hline & $\mathrm{df}$ & 45 \\
\hline & Sig. & .000 \\
\hline
\end{tabular}

Table 5. Total Variance Explained

\begin{tabular}{cccccccccc}
\hline \multirow{2}{*}{ Component } & \multicolumn{3}{c}{ Initial Eigenvalues } & \multicolumn{3}{c}{$\begin{array}{c}\text { Extraction Sums of Squared } \\
\text { Loadings }\end{array}$} & \multicolumn{3}{c}{ Rotation Sums of Squared Loadings } \\
\cline { 2 - 10 } & Total & $\begin{array}{c}\% \text { of } \\
\text { Variance }\end{array}$ & Cumulative \% & Total & $\begin{array}{c}\text { \% of } \\
\text { Variance }\end{array}$ & Cumulative \% & Total & $\begin{array}{c}\text { \% of } \\
\text { Variance }\end{array}$ & Cumulative \% \\
\hline 1 & 4.429 & 44.290 & 44.290 & 4.429 & 44.290 & 44.290 & 4.101 & 41.008 & 41.008 \\
2 & 3.021 & 30.215 & 74.505 & 3.021 & 30.215 & 74.505 & 3.350 & 33.496 & 74.505 \\
3 & .693 & 6.926 & 81.430 & & & & & & \\
4 & .659 & 6.588 & 88.018 & & & & & & \\
5 & .339 & 3.390 & 91.408 & & & & & & \\
6 & .241 & 2.410 & 93.818 & & & & & & \\
7 & .215 & 2.153 & 95.971 & & & & & & \\
8 & .187 & 1.871 & 97.842 & & & & & & \\
9 & .132 & 1.317 & 99.158 & & & & & & \\
10 & .084 & .842 & 100.000 & & & & & & \\
\hline
\end{tabular}

Table 6. Rotated Component Matrix

\begin{tabular}{lll}
\hline & Component & \\
\hline & factor 1 & factor 2 \\
\hline 10.) I feel like I am part of something great at the Organization & .890 & \\
7.) I am able to choose how best to complete my work. & .864 & \\
6.) I play a key role in my Organization & .818 & \\
8.) I am appropriately involved in decisions that affect my work. & .809 & \\
5.) I am very involved in my work & .789 & \\
\hline
\end{tabular}


9.) I like the kind of work I do.

.752

3.) I am unhappy/depressed due to work

2.) I am constantly under stress

.930

1.) I have lost sleep due to stress at work

4.) I am unable to overcome the difficulties easily

.836

\subsubsection{Factor Variable 1}

Like the Job

- Feel like part of something great at the Organization have the higher influence.

- The kind of work done has the lower influence.

\subsubsection{Factor Variable 2}

It's a Stressful Job

- Unhappy/depressed due to work has the higher influence.

- Unable to overcome the difficulties easily has the lower influence.

After identifying the factors, I have analyzed whether there is any difference between respondents of different age group, experience, salary with these factors.

\section{Findings, Suggestions and Conclusion}

\subsection{Findings}

- Majority of the employees, i.e., $43.3 \%$ are in the $30-41$ yrs age group, $42 \%$ are in the $18-29$ yrs age group and $14.7 \%$ are in the $>42$ yrs age group.

- Majority of the employees, i.e., $56 \%$ of the respondents are male and $44 \%$ of the respondents are female in the company.

- Majority of the employees, i.e., $63.3 \%$ of the respondents are Under Graduates, $28.7 \%$ of the respondents are Post Graduates and $8.0 \%$ of the respondents are others.

- Majority of the employees, i.e., 74\% of the respondents are Married,26\% of the respondents are Single.

- $\quad$ Based on work experience, $20 \%$ of the respondents are $<3$ yrs, $48 \%$ of the respondents are $3-10 y r s a n d$ $32 \%$ of the respondents are $>10 y$ rs.

- $\quad$ Based on Salary range, $21.3 \%$ of the respondents are getting $10000-25000,42.7 \%$ of the respondents are getting $25000-60000$ and $36 \%$ of the respondents are getting $>60000$.

- Based on nature of employment, $92.7 \%$ of the respondents are Permanent, $7.3 \%$ of the respondents are Temporary.

- All the sixteen statements on job satisfaction are grouped into four factors namely, organizational factors, relationship with coworkers, support, quality and procedures and other benefits..

- It is inferred that there is association between chances for advancement in the organization and job satisfaction of the employees.

- It is inferred that there is an association between job satisfaction of the respondent and relationship with the co-workers.

- It is inferred that there is an association between job satisfaction of the respondent provided by the company and quality policy of the organization.

- It is inferred that there is other benefits such as Medical insurance policies and educational support and job satisfaction of the respondent.

- It is inferred that there is an association between being part of the organization and psychological well being of the respondent.

- It is inferred that there is less influence association between kind of work done by the respondent and psychological well being of the respondent. 
- It is inferred that there is association between feeling unhappy/depressed due to work of the respondent and psychological well being of the respondent.

- It is inferred that respondents who are above 42 say they like the job and they didn't feel the job stressful.

- It is inferred that the Post Graduate like the job very much and didn't feel stressful.

- It is inferred that the respondents who have experience $>10 y$ rs like the job.

- It is found that it is due to the continue feedback that they get from their managers makes them to feel satisfied with the career aspiration provided by the company.

\subsection{Suggestions}

- Flex time scheduling is an option that allows employees, within specific parameters to decide when to go to work. The plan may reduce absenteeism, leave and increase individual job satisfaction for the employees.

- Engaging with the employees is one of the keys to high performance and may implement new policies to facilitate change. Developing people through enlightened HR and management practices provides a competitive edge.

- Create a sense of purpose and focus employees on what is important and meaningful to them in work. A sense of purpose and direction is important for teamwork, since it instills a sense of pride in employees and engenders job satisfaction.

- Make your employees partners in progress. Believe in your employees and empower them. Give employees more authority over their work and engage them in decision making process and trust them to make the right decisions and act in the best interests of the company.This will increase their responsibilities, challenging job profiles, confidence and create involvement in their jobs.

This will not only improve their skills but also enhances their job satisfaction, as well asto prepare effectively to take over the mantle in the future.

- The organization may give verbal encouragement, recognizing achievement publicly in meetings or company newsletters and rewarding effort to clear misconceptions, quell rumours and gain formal/ informal feedback and suggestions that are essential for managing through the tough times.

- Reinforce the right behaviour. Reward right behaviour and destroy the de-motivators (like office politics and cut throat competition), ill will and dissatisfaction among the employees.

- Encourage employees to have fun. An atmosphere of fun at work facilitates better communication and rapport among the employees. When people work in an environment that is enjoyable, they are apt to be more creative, more productive, get along well with co-workers and remain enthusiastic and motivated in the long run.

\subsection{Conclusion}

People are the most valuable assets of an organization. Only when employees are treated like they matter, they respond with enthusiasm.

The objectives of the project were to know about the employee's satisfaction level. The study also dealt with the effect of psychological well being on job satisfaction. The objectives set for the project have been achieved successfully with use of an appropriate research methodology. Inference have been drawn from the data collected through questionnaire.

Interpretations have been derived with the help of the statistical tools. These interpretations were used for giving the suggestions and recommendations for the growth of the company's business.

The present study has proved the importance of employee satisfaction in an organization. However, in Fred Luthans (1998) opinion, the level of job satisfaction among the employees in an organization requirement or point of departure, is of value to the organizations overall health and effectiveness and is deserving of the study and applications in the field of organization behaviour. If the suggested steps may be taken, then definitely it will lead to happy and productive employee with no fatigue in any kind of situation which definitely will add competitive edge for the organizations.

Job satisfaction and psychological well-being has been measured and less correlation has been found between the both, in the present study, job is a part of life and job satisfaction contributes towards enhancing the feeling of an overall well-being. 
The present study has revealed that the people with high levels of satisfaction and motivation are an asset to any organization: and they will display a positive attitude and cheerfulness, at all times. They adapt to change quickly, and think nothing of working hard or going the extra mile for the organization. Thus, the study reveals that focus on enhancing positive attitudes among the employees is crucial not only for the organization but also for the health and well-being of the employees. When the job satisfaction among the employees increases, subsequently the psychological trauma among the employees reduces and leads to a well-balanced and healthy well-being among the employees.

\section{References}

Bradburn, N. (1969). The structure of psychological well-being. Satisfaction with life scale, Chicago: Aldine.

Campbell, A. (1976). Subjective measures of well-being. American psychologist. https://doi.org/10.1037/0003-066X.31.2.117

Chekola, M. G. (1975). The Concept of Happiness. Doctoral Dissertation, University of Michigan. Dissertation Abstract International, vol. 35

Diener, E., \& Locas, R. E. (1999). Personality and subjective wellbeing. In D. Kahnema, E. Diener \& N. Schwarz (Eds.), Well-being: the Foundation of Hedonic Psychology. New York: Russell Sage Foundation.

Jex, S. M., \& Beehr, T. A. (1991). Emerging theoretical and methodological issues in the study of work related stress.

Joseph, S., \& Lewis, C. A. (1998). The depression happiness scale: reliability and validity of a bipolar scale. $\begin{array}{llrl}\text { Journal of Clinical } & \text { Psychology, }\end{array}$ https://doi.org/10.1002/(SICI)1097-4679(199806)54:4<537::AID-JCLP15>3.0.CO;2-G

Krol, B., Sanderman, R., \& Suurmeijer, T. (1993). Social support, rheumatoid arthritis and quality of life: concept, measurement and research. Patient Edu Couns. https://doi.org/10.1016/0738-3991(93)90125-G

Oshi, S., Diener, E., Suh, \& Lucas, R. (1999). Moderators in Subjective Well-Being. Journal of personality, 64. https://doi.org/10.1111/1467-6494.00051

Schabraq, M., \& Cooper, C. (1998). Toward a phenomenological framework and organizational stress. Hum. Relations, 51(5), 625-648. https://doi.org/10.1177/001872679805100503

Warr, P. (1978). A Study of Psychological Well-being. British Journal of Psychology, 69. https://doi.org/10.1111/j.2044-8295.1978.tb01638.x

\section{Copyrights}

Copyright for this article is retained by the author(s), with first publication rights granted to the journal.

This is an open-access article distributed under the terms and conditions of the Creative Commons Attribution license (http://creativecommons.org/licenses/by/4.0/). 